\title{
The history of healing laid bare
}

\author{
The Greatest Benefit to Mankind: A \\ Medical History of Humanity from \\ Antiquity to the Present \\ by Roy Porter \\ HarperCollins:1997. Pp. 831. £24.99. \\ To be published in the United States by \\ Norton in April at $\$ 35$

\section{Alfred W.Crosby}

I intend to keep this book within reach for years to come. It matches the older histories of medicine in quality, and supersedes them in its coverage of many areas, especially the current situation with AIDS and rocketing medical costs. And its bibliography is truly useful, being selective rather than pseudocomprehensive and stupefying.

This is a history specifically of medicine, not of myriad related matters such as medical beliefs, health, quackery and demography, although these are granted space whenever they are so important that it would be absurd to exclude them, for example the population crashes triggered by the European invasions of America and Africa. Many pages are devoted to institutional history, such as the growth of hospitals, medical schools and research institutions, to the professionalization of healing, to medical societies and systems of certification, and to the intervention of the state in medical matters.

Such tomes as this should be factually flawless but never are. Sorry, Professor Porter, 30 were not executed for witchcraft at Salem, Massachusetts, though 20 were. And 40,000 did not die of measles in Hawaii in 1848, but more like 10,000. Other critics with different funds of specialist knowledge will probably find other errors to carp about. Writing a history book without mistakes is like living a life without sin: worth the effort, but impossible.

A book of this scope should be judged not on picky detail but on how well it achieves what the author intended. The subtitle of this one is A Medical History of Humanity (I'll get to the main title in a bit). Of all humanity? Nonsense. As it is, the book stretches itself as thin as a good history of Western medicine will go without tearing, with token chapters on Indian and Chinese medicine. It is an example of what multiculturalists call 'the West and the rest' school of historiography.

We might be able to pay proper respect to non-Western medical traditions and, on the same page, grant that antibiotics are better for plague than moxibustion if we give up our habit of dividing the history of medicine geographically and divide it chronologically. From the last Ice Age to about 200 or so years ago, nothing much happened in the way of curing infections and dealing with rebellious appendixes. Then something did happen, the 'great acceleration'. It happened demographi-

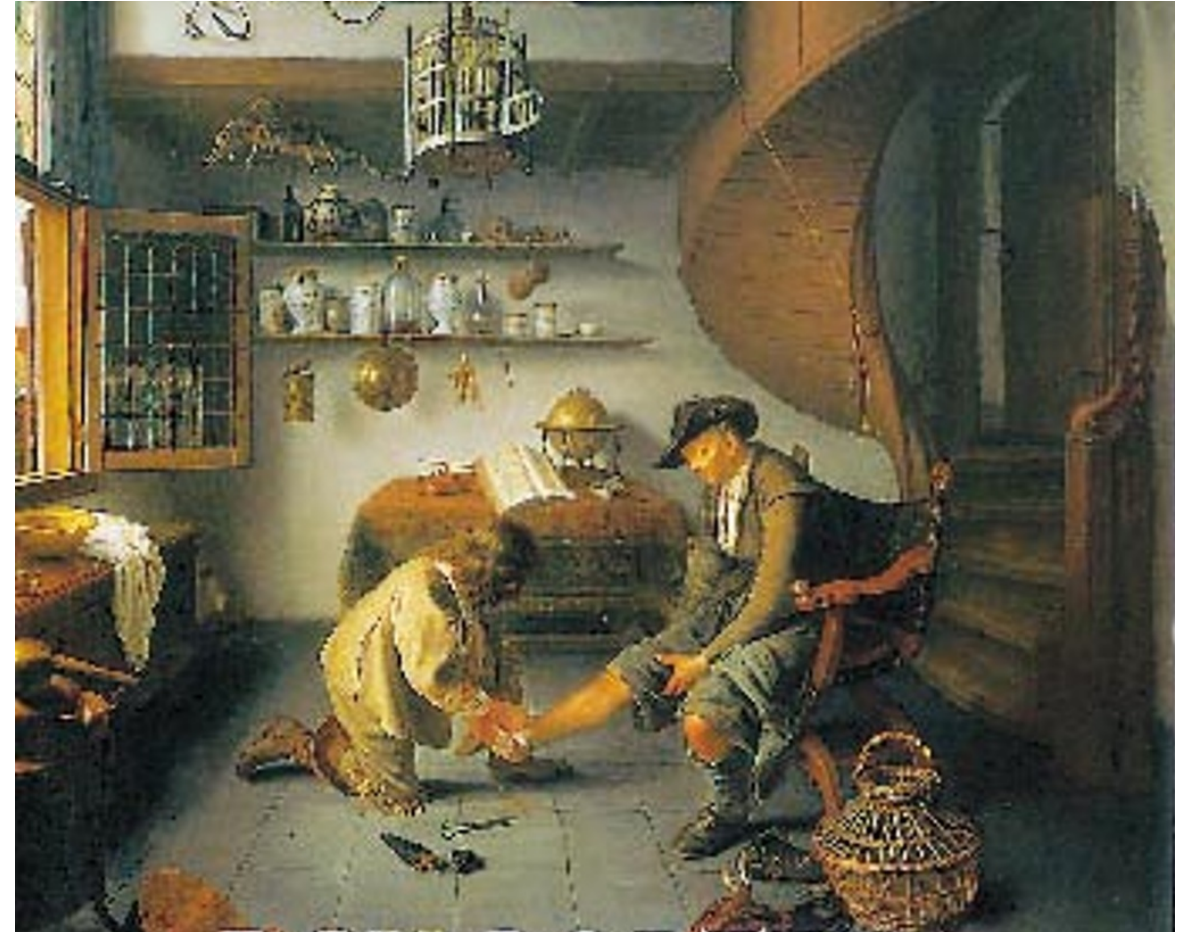

A Barber Surgeon Tending a Peasant's Foot by Isaac Koedijck, 1650, from the cover of Porter's book.

cally, industrially, technologically, in science in general, and in medicine too. It started in the West, but spread with unprecedented swiftness. One of the top bacteriologists in the world at the end of the nineteenth century was Shibasaburo Kitasato, and at the end of the twentieth century the Swedes are giving Nobel prizes for physiology or medicine to people who really don't look like Swedes at all.

I recommend that we should clump medical history before the eighteenth century into one category with two divisions: folk medicine and rational medicine. The first produced much of value, such as smallpox variolation, but could not develop any further than it did because it was a matter of magic or pure and stifling empiricism.

Rational medicine (diagnosis and treatment on the basis of careful observation and logical analysis) did not cure many, but neither did it kill many, and it created a philosophical base for scientific medicine. Some of its practitioners were Greek, some Ayurvedic, some Chinese, some Arabic. They spoke of humours, of health being a matter of balances, of matching the cycles of the body with those of the cosmos; they all strike me as sounding much more like each other than like Westerntrained physicians since the therapeutically nihilist, autopsy-centred Paris tradition of the early 1800 s.

Arranging medical history chronologically saves us from ranking Hippocrates as somehow better than the best of today's Asian physicians, and leaves us with the real mys- tery: why did modern medicine burst onto the scene when and where it did?

Porter pays homage to that explosion by devoting the entire middle of his book to Western medicine in the nineteenth century. This is textbook history at its best and worst. All the names you remember (or should remember) are there: Liebig, Bernard, Lister, Pasteur, Koch, Virchow, Semmelweis, Nightingale and on and on, each with date, place of birth and achievements. Every sentence can be justified, but after 50 or so pages it feels like trying to understand New York city by leafing through its telephone directory.

The chapters on the specifics of research science, public health, bacteriology, psychiatry, immunology and so on in the nineteenth and twentieth centuries make up the bulk of the book, and for many students will be the most valuable. They would have made better reading if Porter had cranked himself up out of the ocean of details to a higher level of abstraction, but that would make a different kind of book from what he intended.

In the final chapters Porter battles successfully against the avalanche of details about the course of medicine in our century, its soaring triumphs, mountainous costs, and decline in public esteem. These are the best chapters because he matches strong opinions to his mastery of the facts. His final sentences sum up medicine's history and its current dilemma. For millennia it attempted little, and failed at that. Today it has accomplished what would have been called near miracles as 
recently as 1900. But the public has expectations beyond even this. His book ends with the thought that "medicine will have to redefine its limits even as it extends its capacities".

The book's main title is The Greatest Benefit to Mankind. There are solid and obvious arguments to support that claim for medicine. But the past is full of bitter ironies, and so may be the future. If the antibiotic revolution produces more antibiotic-resistant pathogens than it counters - or if medicine continues to drive death rates down and live birth rates up, swamping the planet with people - will our descendants still think of it as humanity's greatest benefit?

Alfred W. Crosby is at the Renvall Institute,

University of Helsinki, PO Box 59, 00014 Finland.

\section{Industrial revolutions}

\section{The One Best Way: Frederick Winslow Taylor and the Enigma of Efficiency \\ by Robert Kanigel \\ Viking/Little, Brown: 1997. Pp. 675. \$34.95,

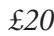

\section{Endless Novelty: Specialty Production and American Industrialization \\ by Philip Scranton \\ Princeton University Press: 1997. Pp. 415. $\$ 39.50, £ 29.95$}

\section{DavidE. Nye}

How should we tell the story of the second industrial revolution, which began in the United States in the late nineteenth century and by the 1920s resulted in massive productivity increases, high wages and the growth of consumer society? Philip Scranton and Robert Kanigel offer quite different answers to this question.

Kanigel tells the more familiar story in The One Best Way, a biography of Frederick Winslow Taylor, a founder of scientific management. Taylor believed that industrial work could be reduced to scientific principles. There was "one best way" to do any job, and once this was discovered by an expert, stopwatch in hand, workers were to conform to the system. Taylor would teach the most efficient movements and invent the ideal tools for even the simplest task. Workers who cooperated were more productive, and, in return, managers were expected to pay them more.

Educated in European schools and at the Phillips Exeter Academy in New Hampshire before he chose a machine shop over Harvard, Taylor was a persuasive speaker and writer. After 1908 he lectured annually at Harvard Business School, and his paper trail is more enticing than that of the managers and workers who opposed him. In lively prose sprinkled with anecdotes, Kanigel describes Taylor's privileged boyhood in Philadelphia, his choice of practical work over gentility, and

\section{THEY ALL WANT MR. BRANDEIS NOW}

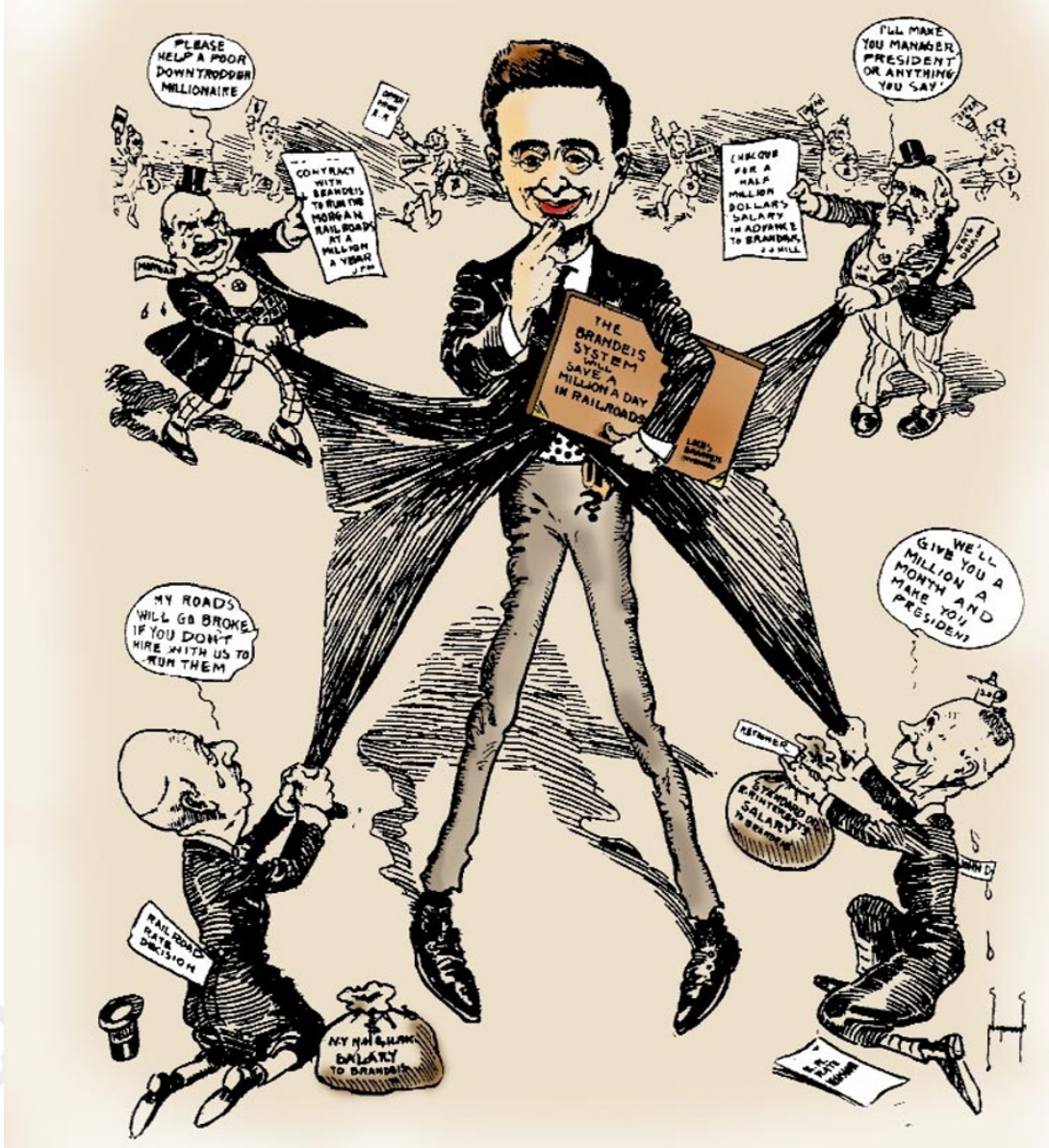

Boston lawyer Louis Brandeis was the instrument of Taylor's rise to fame. In a case in which Brandeis opposed some US railroad companies' application for an increase in freight tariffs, he championed the system of 'scientific management', lecturing the companies on how they could save millions of dollars.

his rise from the shop-floor to champion rationality and efficiency. His principles, Kanigel argues, reshaped contemporarylife in a thousand subtle ways. "Taylor's impact was like that of Darwin, Marx, and Freud", for each brought an analytical "cast of mind to an unruly, seemingly intractable problem”.

Kanigel is better on Taylor's ancestry, education and career than on his place in industrial history. His portrayal of Taylor is more sympathetic than (and three times as long as) Daniel Nelson's 1980 biography, and is perhaps overly detailed in recounting Taylor's private life. Kanigel's Taylor is not so much arrogant as self-assured, owing to a good family background. His eye problems and headaches, which prompted him to abandon formal schooling, are not psychosomatic but caused by poorly understood astigmatism. Frequent conflicts with both workers and managers are caused less by insensitivity than by a theatrical personality. Overall, he appears less an eccentric than a bull-headed individualist.

Taylor's ideas had enormous resonance beyond the factory in home economics, education, religion and popular culture. His Princi- ples of Scientific Management sold widely in French, German and Russian translations, and was praised by Lenin. Taylor was lionized by Louis Brandeis and later by many who were prominent in the New Deal. Yet labour leaders loathed hisideas, which were subjected to some rather hostile congressional hearings in 1912.

Kanigel argues that Taylor's system largely anticipated the assembly line. This is nonsense. Taylor made shovelling more efficient; Ford used electrified machines to eliminate shovelling. Taylor retained piece-work, a concept that makes no sense on the assembly line, where all share the same pace. Taylor maximized efficiency in existing production; Ford transformed the means of production. Taylor saved time; Ford sped up time.

In 1914, after Taylor imposed his system on the Packard Motor Company, its 4,525 workers produced 2,984 cars a year, less than one per man. This was still artisanal production of a luxury vehicle. Ten years earlier, well before the assembly line, Ford was already producing 12 cars for every worker. By 1914, 13,000 Ford employees, using conveyor belts, electric cranes and 15,000 specialized machine tools, manufactured 260,000 cars, or 